\title{
PENGARUH VARIASI BENTUK SUDU TERHADAP KINERJA TURBIN AIR KINETIK (Sebagai Alternatif Pembangkit Listrik Daerah Pedesaan)
}

\author{
Ahmad Yani ${ }^{\left.1, a^{*}\right)}$, Mihdar ${ }^{2, b)}$, Rudi Erianto ${ }^{3, c)}$ \\ Jurusan Teknik Mesin Fakultas Teknik Universitas Trunajaya Bontang.) 1,2,3 \\ JI.Taekwondo RT.9 No. 55 Telp./Fax. (0548) 3035920 Bontang-Kaltim 75311 \\ Email: yanibima@gmail.com ${ }^{\text {a) }}$, mihdar.mdr02@gmail.com ${ }^{\text {b) }}$, rudi.respector90@gmail.com ${ }^{\text {c) }}$
}

\begin{abstract}
Abstrak
Turbin air kinetik adalah salah satu turbin yang memanfaatkan potensi energi kinetik berupa kecepatan aliran, dimana penelitian ini menggunakan turbin kinetik poros vertikal yang bersudu mangkuk. Penelitian dilakukan dengan menggunakan suatu instalasi turbin kinetik, dan dilakukan pengukuran terhadap gaya dan putaran dengan variasi bentuk sudu. Bentuk sudu turbin air kinetik merupakan salah satu variabel yang mempengaruhi putaran dan gaya tangensial suatu turbin, sehingga efeknya terhadap nilai daya dan efisiensi sebuah turbin air kinetik. Metode penelitian yang digunakan adalah metode eksperimen dengan rancangan percobaan berskala laboratorium. Hasil penelitian menunjukan adanya pengaruh bentuk sudu terhadap daya dan efisiensi yaitu bentuk sudu lengkung memiliki efisiensi lebih tinggi dibandingkan dengan bentuk sudu datar dan mangkuk. Daya dan efisiensi turbin maksimum terjadi pada sudu lengkung dengan nilai sebesar 4,699 Watt dan 29,659 \%, kemudian menurun pada sudu mangkuk dengan nilai daya dan efisiensi sebesar 4,508 Watt dan $28,457 \%$. Sedangkan daya dan efisiensi turbin terendah terjadi sudu datar dengan nilai daya dan efisiensi sebesar 3,080 Watt dan 19,439\%.
\end{abstract}

Kata Kunci : Turbin kinetik, bentuk sudu,daya dan efisiensi turbin.

\section{Pendahuluan}

Berdasarkan data Outlook Energy Indonesia atau Badan Pengkajian dan Penerapan Teknologi (2015), proyeksi kebutuhan listrik per sektor pada tahun 2016 kebutuhan tenaga listrik nasional berturut-turut adalah sebesar 190 TWh dan 232 TWh, dengan sektor rumah tangga pada kedua tahun tersebut masih mendominasi dengan pangsa lebih dari $41 \%$. Sedangkan sektor industri mempunyai pangsa dikisaran $34 \%$, diikuti oleh sektor komersial (24\%), dan sektor transportasi $(0,1 \%)$. Selama periode 2013 s.d. 2050, kebutuhan tenaga listrik total di semua sektor diperkirakan akan terus meningkat secara signifikan hingga lebih dari 10 kali, yaitu akan mencapai 2.008 TWh pada tahun 2050 atau tumbuh sebesar $6,6 \%$ per tahun. Kemudian, mengenai kebutuhan listrik per kapita, pada tahun 2013 hanya sebesar $764 \mathrm{kWh}$ per kapita, dua belas tahun kemudian diprediksi naik hampir tiga kali lipat menjadi $1.987 \mathrm{KWh}$ per kapita. Pada tahun 2050 diprediksi akan mencapai $6.112 \mathrm{kWh}$ per kapita.[1]

Energi air dapat dimanfaatkan sebagai pembangkit listrik dengan memanfaatkan tenaga potensial yang tersedia (potensi air terjun dan kecepatan aliran). Indonesia memiliki potensi besar untuk mengembangkan pembangkit listrik tenaga air. Ini disebabkan kondisi topografi Indonesia yang bergunung dan berbukit serta dialiri oleh banyak sungai (besar dan kecil) dan di beberapa daerah tertentu terdapat danau dan waduk yang cukup potensial sebagai sumber energi air.

Pembangkit Listrik Tenaga Air (PLTA) adalah pembangkit yang 
memanfaatkan aliran air sebagai sumber untuk membangkitkan listrik. Pemanfaatan tenaga air kecepatan rendah salah satunya dengan menggunakan turbin kinetik. Dimana turbin ini memanfaatkan Potensi energi kinetik berupa kecepatan aliran air dari sungai. Arus aliran air langsung menumbuk sudu turbin yang dapat menyebabkan runner berputar sehingga terjadi perubahan energi kinetik air menjadi energi mekanis pada turbin yang digunakan untuk menggerakan generator kemudian menjadi energi listrik. [5]

Bentuk sudu turbin sangat menentukan putaran turbin dimana dengan tepatnya penentuan bentuk sudu akan mempengaruhi kecepatan tangensial yang memutar roda turbin untuk meningkatkan kinerja turbin. Untuk itu maka penelitian ini diarahkan untuk menentukan bentuk sudu yang tepat untuk menghasilkan kinerja turbin yang maksimal maksimal.

Penelitian ini dilakukan bertujuan untuk mengetahui pengaruh variasi bentuk sudu terhadap kinerja turbin air kinetik. Pembahasan pada penelitian ini dapat dibatasi pada kondisi-kondisi:

1. Posisi poros turbin vertikal

2. Debit air $0,0078 \mathrm{~m}^{3} / \mathrm{s}$

3. Pengujiandilakukan pada skala laboratorium dengan metode pengereman putaran turbin.

4. Sudu yang divariasikan adalah sudu datar, sudu lengkung dan sudu mangkuk.

5. Tidak membahas segitiga kecepatan turbin dan kerugian aliran air.

\section{Tinjauan Pustaka}

Turbin air terdapat dalam suatu pembangkit listrik berfungsi untuk mengubah energi potensial yang dimiliki air menjadi energi kinetik. Selanjutnya energi kinetik ini akan dirubah menjadi energi elektrik melalui generator. Hal ini menyebabkan setiap pembahasan tentang turbin hidrolik akan mengikutsertakan generator sebagai pembangkit listrik.

Turbin air adalah salah satu mesin penggerak yang mana fluida kerjanya adalah air. Berdasarkan perubahan energi turbin air dibedakan menjadi dua kelompok yaitu turbin Impuls dan turbin reaksi.

\section{Pengertian Turbin Kinetik}

Turbin air kinetik adalah suatu alat yang dapat menghasilkan energi mekanik berupa putaran poros dengan mengandalkan kecepatan aliran air dari sungai dan memanfaatkan energi kinetik air, energi kinetik air selanjutnya diubah menjadi energi mekanis pada turbin yang digunakan untuk menggerakkan generator sehingga menjadi energi listrik. Turbin kinetik hanya mengandalkan kecepatan air, sehingga turbin jenis ini tidak membutuhkan tinggi jatuh (head) air. Turbin ini sangat tepat untuk dipakai pada daerah yang datar yang memiliki aliran sungai, terutama daerah pedesaan. Sampai saat ini dikenal dua jenis turbin kinetik, yaitu turbin kinetik dengan poros horizontal dan turbin kinetik berporos vertikal. Turbin yang di pergunakan dalam penelitian ini adalah turbin kinetik yang porosnya diletakan secara vertikal.

\section{Prinsip Kerja Turbin Kinetik}

Turbin kinetik bekerja dimana arus aliran air langsung menumbuk sudu turbin tanpa melalui nozel. Energi diberikan kepada sudu berupa energi kinetik atau energi kecepatan. Pada turbin kinetik vertikal (tegak) air langsung menumbuk sudu pada setengah bagian roda turbin sedangkan setengah bagian yang lain juga mendapat tumbukan tetapi tidak sebesar setengah bagian yang pertama sehingga turbin masih bisa berputar.[3]

\section{Kinerja Turbin Kinetik}

Turbin air yang diteliti adalah peralatan mekanis berbentuk roda pada poros vertikal. Turbin air ini memanfaatkan kecepatan aliran. Air yang masuk ke dalam dan keluar turbin tidak mempunyai tekanan lebih (over pressure). Dalam pengujian turbin air kinetik hasil yang diharapkan adalah mendapatkan daya dan efisiensi. Proses perhitungan dengan 
mempergunakan persamaan berikut $:[2,3,4,5]$

\section{Luas Penampang Saluran (A)}

Persamaan untuk menghitung ujung luas saluran yang menumbuk sudu turbin adalah :

$$
A=P . L
$$

\section{Kapasitas Aliran (Q)}

Untuk menghitung kapasitas aliran, digunakan persamaan :

$$
Q=A \cdot V
$$

\section{Laju Massa Air yang Mengalir ( $\dot{m})$}

Massa aliran digunakan persamaan :

$$
\dot{m}=\rho \cdot Q
$$

Daya Air yang Mengalir $\left(P_{a}\right)$

Daya air dapat dihitung dengan mempergunakan persamaan :

$$
P_{a}=\frac{1}{2} \rho \cdot A \cdot V^{3}
$$

\section{Torsi Turbin (T)}

Besarnya torsi dapat dihitung dengan persamaan :

$$
T=F \cdot R
$$

Dimana :

$$
\begin{aligned}
& \mathrm{F}=\text { Jumlah gaya, }(\mathrm{N}) \\
& \mathrm{R}=\text { Radius Pully, }(\mathrm{m})
\end{aligned}
$$

\section{Kecepatan Anguler ( $\omega$ )}

Untuk kecepatan keliling turbin diperoleh dengan menghitung menggunakan persamaan :

$$
\omega=\frac{2 \cdot \pi \cdot n}{60}
$$

\section{Daya Turbin $\left(\boldsymbol{P}_{t}\right)$}

Daya turbin dihitung dengan persamaan :

$$
P_{t}=T . \omega
$$

\section{Efisiensi Turbin $\left(\eta_{t}\right)$}

Efisiensi dapat dihitung dengan persamaan

$$
\eta_{\eta t}=\frac{P_{a}}{P_{t}} \times 100 \%
$$

\section{Metode Penelitian}

\section{Alat dan Bahan}

a. Instalasi Turbin Kinetik

b. Instalasi Pompa

c. Alat Ukur

- Tachometer untuk mengukur putaran turbin

- Neraca Pegas untuk mengukur gaya dari beban putaran turbin

\section{Variabel Penelitian}

Variabel yang digunakan pada penelitian ini terdiri dari; variabel bebas, variabel terikat dan variabel terkontrol.

a. Variabel Bebas

Variabel bebas adalah variabel yang ditentukan nilainya sebelum dilakukan penelitian terdiri dari :

1. Variasi bentuk sudu sudu : datar, lengkung dan mangkuk seperti ditunjukan gambar 1,2, dan 3 .
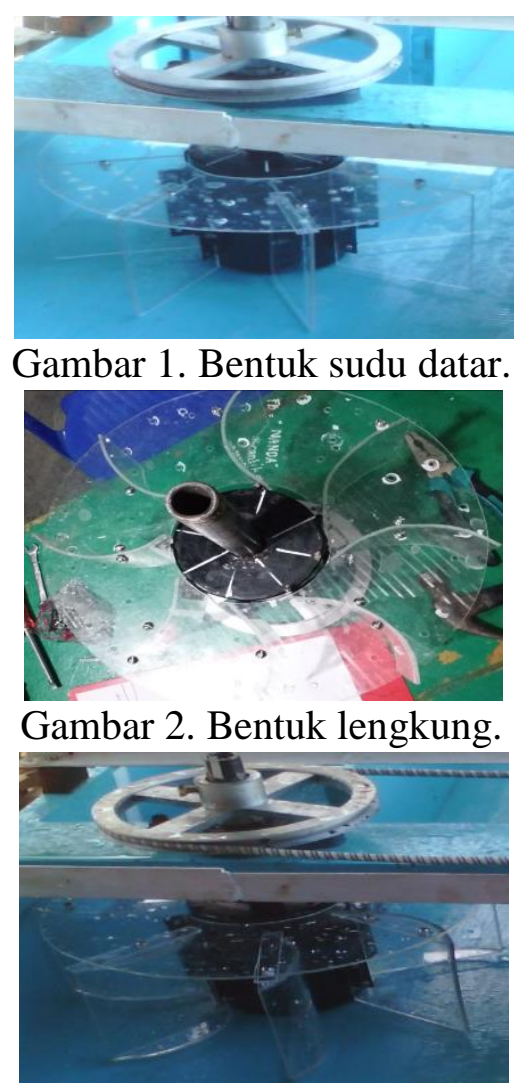

Gambar 3. Bentuk sudu mangkuk.

2. Debit air : $0,0078 \mathrm{~m}^{3} / \mathrm{s}$

3. Putaran turbin dikondisikan konstan pada $90,70,50,30,10$, dan $0 \mathrm{rpm}$. 
b. Variabel Terikat

Variabel terikat adalah variabel yang nilainya sangat tergantung pada variabel bebas dan merupakan hasil dari penelitian. Variabel terikat yang diperoleh dalam penelitian ini adalah:

1. Daya turbin air kinetik

2. Efisiensi turbin air kinetik

c. Variabel Terkontrol

Variabel terkontrol adalah Putaran turbin yang ditentukan untuk mengukur besaran gaya $(90,70,50,30$, dan $10 \mathrm{rpm})$

1. Jumlah sudu 8 buah.

2. Sudut sudu dikondisikan konstan pada posisi $10^{0}$ (backward).

3. Sudut pengarah aliran dikondisikan konstan pada posisi $25^{\circ}$.

\section{Tempat dan Waktu Penelitian}

Penelitian ini dilaksanakan di jalan Pangeran Antashari RT. 06 Kelurahan Berbas Pantai - Kecematan Bontang Selatan dan waktu penelitian dimulai Bulan Desember 2015 sampai Bulan Januari 2016.

\section{Prosedur Penelitian}

1. Menyiapkan dan memasang semua instalasi penelitian.

2. Memasang alat ukur yang dibutuhkan.

3. Mengecek kondisi alat ukur beserta alat pendukung lainnya.

4. Menvariasikan bentuk sudu turbin sesuai dengan bentuk sudu yang telah ditetapkan yaitu sudu datar, sudu lengkung dan sudu mangkuk.

5. Menghidupkan pompa untuk menyalurkan air.

6. Mengatur debit air dengan cara perhitungan atau pengukuran aliran air dengan menggunakan metoda waktu pengisian.

7. Mengukur putaran poros turbin dengan alat ukur tachometer tanpa beban terlebih dahulu. Selanjutnya mengukur putaran poros turbin dengan beban yang diberikan secara pelan-pelan dengan cara memutar tuas penyetel beban gaya sampai memenuhi putaran yang divariasi yaitu $90 \mathrm{rpm}, 70 \mathrm{rpm}, 50 \mathrm{rpm}, 30 \mathrm{rpm}$, dan $10 \mathrm{rpm}$. Selanjutnya memberikan beban sampai turbin tidak berputar. Kemudian mencatat setiap variasi pengukuran putaran turbin sampai turbin berhenti berputar.

8. Pengujian pada bentuk sudu datar dilakukan tiga kali pengulangan untuk mendapatkan data pengujian yang akurat.

9. Mengulang langkah nomor satu sampai dengan kedelapan pada variasi bentuk sudu lengkung dan bentuk sudu mangkuk.

10. Mengolah data penelitian yang didapatkan.

11. Mengolah dan menganalisa data penelitian yang didapatkan untuk mengetahui hubungan antara variabel yang telah ditentukan.

12. Menarik kesimpulan dari hasil penelitian yang dilakukan.

\section{Instalasi Alat Penelitian}

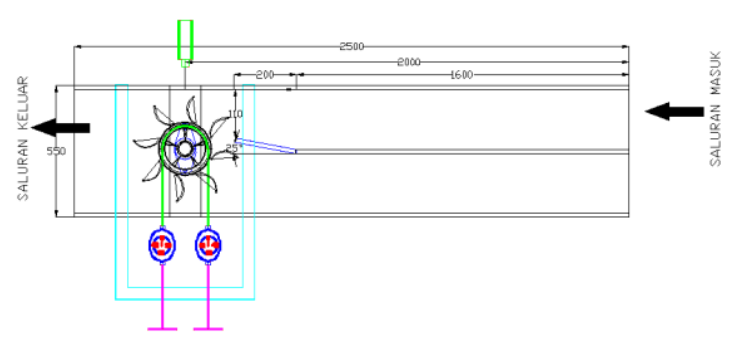

Gambar 4. Desain Instalasi Penelitian.

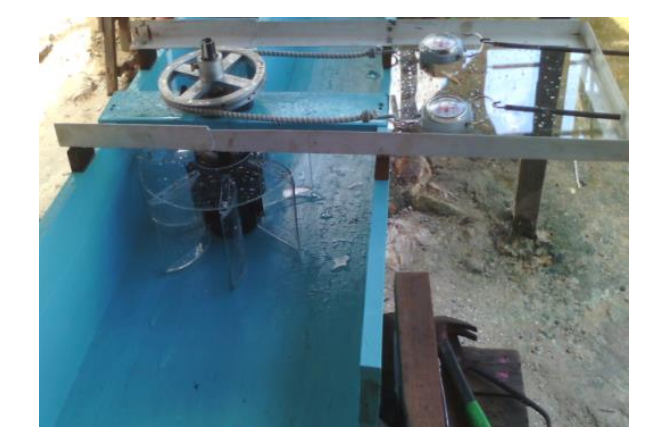

Gambar 5. Alat Penelitian Turbin Air.

\section{Pembahasan Hasil Penelitian}

Dari hasil pengolahan data kemudian dilakukan pembahasan hasil penelitian dengan tujuan untuk mendapatkan nilai dari 
grafik daya dan efisiensi supaya yang membaca penulisan ini mudah memahaminya dan dapat melihat fenomena yang terjadi dari hasil penelitian yang dilakukan.

Pada penelitian ini teknik analisa data menggunakan teknik deskriptif berdasarkan hasil penelitian yang dilakukan. Data yang diperoleh dari hasil penelitian kemudian dianalisis menggunakan rumus terapan, Selanjutnya data akan disajikan dalam bentuk grafik dengan bantuan Microsoft Office Excel untuk menampilkan grafik daya dan efisiensi turbin dari hubungan antara variasi bentuk sudu yang telah ditentukan.

Tabel 1. Data Daya rata - rata dari pengolahan ketiga variasi bentuk sudu.

\begin{tabular}{|c|c|c|c|}
\hline \multirow{2}{*}{$\begin{array}{c}\text { Putaran, } \mathrm{n} \\
\text { (rpm) }\end{array}$} & \multicolumn{3}{|c|}{ Daya P (watt) } \\
\cline { 2 - 4 } & $\begin{array}{c}\text { Sudu } \\
\text { Datar }\end{array}$ & $\begin{array}{c}\text { Sudu } \\
\text { Lengkun } \\
\mathrm{g}\end{array}$ & $\begin{array}{c}\text { Sudu } \\
\text { Mangkuk }\end{array}$ \\
\hline 90 & 1.837 & 3.960 & 3.715 \\
\hline 70 & 3.080 & 4.699 & 4.508 \\
\hline 50 & 2.154 & 4.672 & 4.059 \\
\hline 30 & 2.014 & 3.470 & 3.279 \\
\hline 10 & 0.757 & 1.279 & 1.324 \\
\hline 0 & 0.000 & 0.000 & 0.000 \\
\hline
\end{tabular}

Dari data tabel 1 tersebut kemudian dijadikan dalam bentuk grafik daya turbin. Hubungan antara daya dan putaran pada ketiga variasi bentuk sudu seperti ditunjukkan gambar 6 .

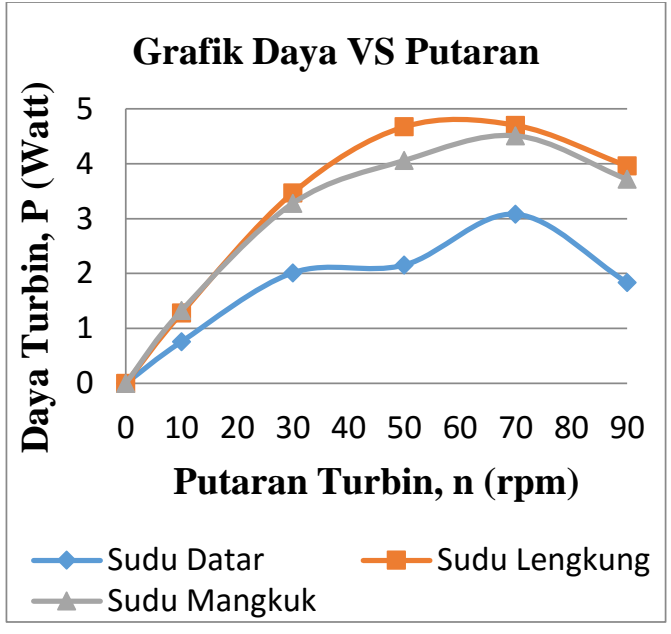

Gambar 6. Grafik hubungan daya dan putaran pada ketiga variasi bentuk sudu.

Pada penelitian ini diberikan tiga variasi bentuk sudu yaitu sudu datar, sudu lengkung dan sudu mangkuk. Berdasarkan gambar 6 daya turbin maksimum terjadi pada sudu lengkung, kemudian menurun pada sudu mangkuk dan daya terendah terjadi pada sudu datar. Daya turbin sangat tergantung pada besarnya torsi dan kecepatan anguler, besarnya torsi dipengaruhi oleh putaran turbin. Daya turbin maksimum terjadi pada sudu lengkung dengan nilai sebesar 4,699 Watt dengan putaran $70 \mathrm{rpm}$, kemudian menurun pada sudu mangkuk dengan nilai daya sebesar 4,508 Watt dengan putaran $70 \mathrm{rpm}$. Sedangkan daya turbin terendah terjadi sudu datar dengan nilai sebesar 3,080 Watt dengan putaran $70 \mathrm{rpm}$.

Tabel 2. Data efisiensi rata - rata dari pengolahan ketiga variasi bentuk sudu.

\begin{tabular}{|c|c|c|c|}
\hline \multirow{2}{*}{$\begin{array}{c}\text { Putaran, n } \\
(\mathrm{rpm})\end{array}$} & \multicolumn{3}{|c|}{ Efesiensi $\eta(\%)$} \\
\cline { 2 - 4 } & $\begin{array}{l}\text { Sudu } \\
\text { Datar }\end{array}$ & $\begin{array}{l}\text { Sudu } \\
\text { Lengkun } \\
\text { g }\end{array}$ & $\begin{array}{l}\text { Sudu } \\
\text { Mangkuk }\end{array}$ \\
\hline 90 & 11.595 & 24.993 & 23.447 \\
\hline 70 & 19.439 & 29.659 & 28.457 \\
\hline 50 & 13.599 & 29.487 & 25.622 \\
\hline 30 & 12.711 & 21.901 & 20.698 \\
\hline 10 & 4.781 & 8.073 & 8.360 \\
\hline 0 & 0.000 & 0.000 & 0.000 \\
\hline
\end{tabular}


Dari data tabel 2 tersebut kemudian dijadikan dalam bentuk grafik efisiensi. Hubungan antara efisiensi dan putaran pada ketiga variasi bentuk sudu seperti ditunjukkan gambar 7.

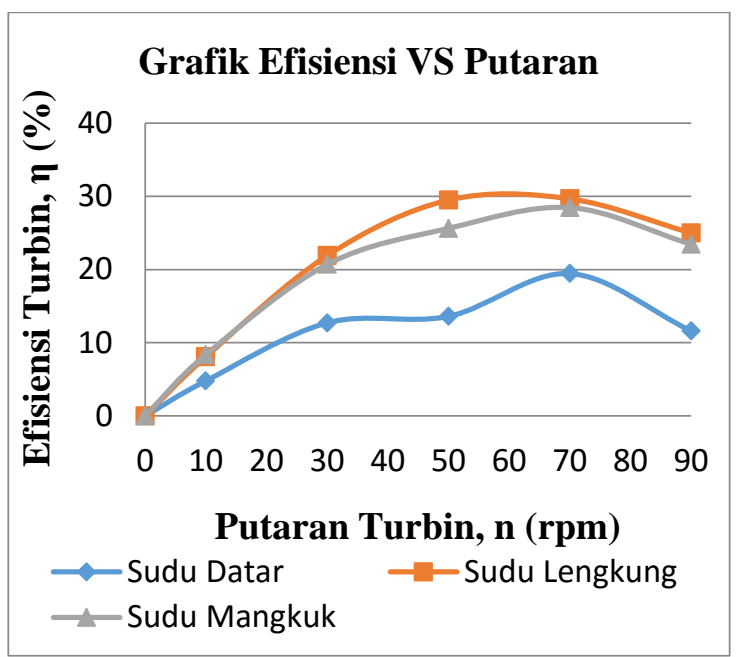

Gambar 7. Grafik hubungan efisiensi dan putaran pada ketiga variasi bentuk sudu.

Pada penelitian ini diberikan tiga variasi bentuk sudu yaitu sudu datar, sudu lengkung dan sudu mangkuk. Berdasarkan gambar 7 efisiensi turbin maksimum terjadi pada sudu lengkung, kemudian menurun pada sudu mangkuk dan efisiensi terendah terjadi pada sudu datar. Efesiensi turbin di pengaruhi oleh daya turbin dan daya air, daya turbin sangat tergantung pada besarnya torsi dan kecepatan anguler, besarnya torsi dipengaruhi oleh putaran turbin, sehingga pada putaran dengan nilai besar akan menghasilkan gaya yang besar dan gaya tersebut berpengaruh terhadap torsi. Efisiensi turbin maksimum terjadi pada sudu lengkung dengan nilai sebesar $29,659 \%$, kemudian menurun pada sudu mangkuk dengan nilai efisiensi sebesar $28,457 \%$. Sedangkan efisiensi turbin terendah terjadi sudu datar dengan nilai efisiensi sebesar 19,439\%.

\section{Kesimpulan}

Hasil penelitian menunjukan adanya pengaruh bentuk sudu terhadap kinerja atau daya dan efisiensi turbin air kinetik yaitu bentuk sudu lengkung memiliki daya dan efisiensi lebih tinggi dibandingkan dengan bentuk sudu datar dan mangkuk. Daya dan efisiensi turbin maksimum terjadi pada sudu lengkung dengan nilai sebesar 4,699 Watt dan 29,659 \%, kemudian menurun pada sudu mangkuk dengan nilai daya dan efisiensi sebesar 4,508 Watt dan 28,457\%. Sedangkan daya dan efisiensi turbin terendah terjadi sudu datar dengan nilai daya dan efisiensi sebesar 3,080 Watt dan $19,439 \%$.

\section{Daftar Pustaka}

[1] Badan pengkajian dan penerapan teknologi (BPPT). (2015). pusat teknologi pengembangan sumberdaya Energi, Jakarta

[2] Irawan, D. Soenoko, R dan Sutikno, D. (2012). "Pengaruh Sudut Sudu Terhadap Kinerja Turbin Kinetik". Prosiding Seminar Nasional Science, Engineering and Technology, Brawijaya Malang.

[3] Ohoirenan. W, Wahyudi. S, dan Sutikno, D, (2012). "Pengaruh Variasi Jumlah Sudu Terhadap Kinerja Turbin Kinetik Roda Tunggal". Prosiding Seminar Nasional Science, Engineering and Technology, Brawijaya Malang.

[4] Rusman,. Soenoko, R. dan Wahyudi. S. (2012). "Pengaruh Sudut Pengarah Aliran Terhadap Kinerja Turbin Kinetik Bersudu Mangkok". Prosiding Seminar Nasional Science, Engineering and Technology, Brawijaya Malang.

[5] Yani. A, Wahyudi. S. dan Denny. W (2012) "Pengaruh variasi panjang sudu mangkok terhadap kinerja turbin kinetik" Prosiding Seminar Nasional Science, Engineering and Technology, Brawijaya Malang. 